\title{
TERAPI BERMAIN PRETEND PLAY UNTUK PERKEMBANGAN KOGNITIF ANAK RETARDASI MENTAL DI SEKOLAH DASAR LUAR BIASA (SDLB) KABUPATEN LAMONGAN
}

\author{
Siti Solikhah \\ Program Studi S1 Keperawatan STIKES Muhammadiyah Lamongan \\ Email : virgianti_nf@yahoo.com
}

\begin{abstract}
Mental retardation is a condition where a person's mental development is stopped or incomplete or it can also be said to be not in accordance with the level of development of his age. The purpose of this study was to determine the effect of pertend play therapy on the cognitive development of mentally retarded children in SDLB Lamongan Regency. The design of this study is the Quasy Experiment (quasiexperiment) with the Pre-Post approach to the Control Design Test, with a purposive sampling technique. The population in this research were some students who experience mental retardation in SDLB Lamongan. Data was carried out from February to March 2018 using the Observation measuring instrument. The results of statistical tests using the Wilcoxon on SPSS Software (version 16.0) obtained results $Z=-3.542 a$ and $p=0.000$ ( $p<0.05)$. The results showed that the pretest of the majority of respondents had less cognitive while the posttest almost most of the respondents had good cognitive.
\end{abstract}

Keywords: Mental Retardation, Pretend Play, Cognitive.

\section{PENDAHULUAN}

Retardasi mental merupakan suatu keadaan dimana perkembangan mental seseorang yang terhenti atau tidak lengkap atau bisa juga dikatakan tidak sesuai dengan tingkat perkembangan anak seusianya. Pada umumnya retardasi mental ditandai dengan intelegensia yang kurang (subnormal), sejak masa perkembangan baik setelah lahir maupun masa kanak-kanak (Subini, 2012). Retardasi mental menurut klasifikasinya dibedakan menjadi ringan, sedang, berat bahkan sangat berat, yang disertai dengan keterbatasan kemampuan fisik sehingga memerlukan perawatan terus-menerus seumur hidupnya (Sutini, Keliat, \& Gayatri, 2014)

Intelegensi yang kurang menyebabkan anak retardasi mental mulai mengalami keterlambatan berbagai hal, antara lain dalam hal menangkap pelajaran, keterampilan merawat diri, keterampilan motorik, pengembangan pemahaman dan penggunaan bahasa. Salah satu kejadian yang dialami oleh anak dengan retardasi mental adalah ketidakmampuan atau kesulitan dalam pelajaran akademik khususnya berhitung (Ariyani, 2013).

Bermain adalah suatu aktivitas yang banyak dilakukan oleh anak-anak. Dapat dikatakan bahwa sebagian besar waktu yang ada pada masa anak-anak digunakan 
untuk bermain. Permainan bagi anak-anak adalah suatu bentuk aktivitas yang menyenangkan yang dilakukan semata-mata untuk aktivitas itu sendiri, bukan karena ingin memperoleh sesuatu yang dihasilkan dari aktivitas tersebut. Hal ini adalah karena bagi anak-anak proses melakukan sesuatu lebih menarik daripada hasil yang akan didapatkannya (Desmita, 2015).

Prevalensi disabilitas termasuk retardasi mental di Indonesia meningkat pada tahun 2003 sampai 2012, yaitu $0,69 \%$ menjadi 2,45\% dari total jumlah penduduk di Indonesia. Meningkatnya jumlah kasus ini menyebabkan sumber daya manusia menurun dan kualitas penduduk di Indonesia juga menurun (Kemenkes RI, 2014). Pada data pokok Sekolah Luar Biasa di seluruh Indonesia tahun 2009, (BPS, 2010) dalam Kemenkes RI (2014) berdasarkan kelompok usia sekolah, jumlah penduduk di Indonesia yang menyandang keterbelakangan mental adalah 62.011 orang. Dengan perbandingan 60\% diderita anak laki-laki dan $40 \%$ diderita anak perempuan. Dari jumlah tersebut anak yang terkena retardasi mental sangat berat sebanyak 2,5\%, anak retardasi mental berat sebanyak 2,8\%, retardasi sedang sebanyak 2,6\%, anak retardasi mental ringan sebanyak 3,5\% dan sisanya disebut anak dungu.

Berdasarkan hasil pengambilan data survey awal yang dilakukan pada tanggal 14 Oktober 2017, terdapat 32 siswa yang bersekolah di SDLB Negeri Lamongan. Dari sejumlah siswa tersebut, dapat diambil 10 orang sebagai sample, dari 10 orang tersebut terdapat 7 orang yang mengalami retardasi mental dan yang 3 tidak mengalaminya. Siswa retardasi mental memiliki kognitif dibawah rata-rata sehingga menyebabkan mereka memiliki kesulitan dalam konsentrasi, membedakan warna dan mengenali bentuk, memahami konsep dan simbol bilangan. Sehingga didapatkan $70 \%$ siswa yang mengalami retardasi mental.

Penyebab retardasi mental adalah faktor genetik (Sindrom Down atau Sindrom Klinefelter), faktor prenatal (paparan prenatal dengan infeksi, toksin, anti konvulsan, atau alkohol), faktor perinatal (komplikasi kehamilan, penyakit pada ibu, kelahiran prematur, berat badan lahir rendah, asfiksia saat lahir), faktor postnatal (infeksi otak, cedera otak, serta malnutrisi parah dan jangka panjang, kerusakan otak saat periode kritis perkembangan pra- atau pascakelahiran), gangguan metabolisme dan gizi, kekurangan yodium, paparan penyakit atau toksin (batuk rejan, campak, paparan merkuri, timbal), serta faktor perilaku atau sosial, seperti kemiskinan, malnutrisi, konsumsi obat-obatan ibu dan alkohol (Ariani, Soeselo, \& Surilena, 2014).

Adanya retardasi mental tersebut menyebabkan gangguan seperti kesulitan dalam konsentrasi, kesulitan membedakan warna dan mengenali bentuk, kesulitan memahami konsep dan simbol bilangan (Kemenkes RI, 2014). Gangguan tersebut menyebabkan lambannya berpikir dan lambatan mengingat jangka pendek yang disebut dengan gangguan kemampuan kognitif. Gangguan kemampuan kognitif tersebut akan mengakibatkan ganguan adaptasi sosial, yang bermanifertasi pada masa perkembangan (Kemenkes RI, 2014). 
Pretend play merupakan cara untuk melibatkan teman-teman situasi sosial pada kehidupan nyata yang sering dilakukan oleh seseorang. Melalui pengalaman langsung, anak-anak dapat belajar untuk memecahkan masalah, memahami, dan dapat menerima orang lain meskipun mereka berbeda. Pretend play adalah suatu cara penguasaan bahan-bahan pelajaran melalui pengembangan imajinasi dan didukung oleh peralatan yang dipakai (Prihtiyaningsih, 2017).

Perkembangan kognitif anak dengan retardasi mental mengalami proses keterlambatan dalam fungsi kemampuan kognitifnya (Somantri, 2012). Teori kognitif berpendapat bahwa manusia membangun kemampuan kognitifnya melalui tindakan yang termotivasi dengan sendirinya terhadap lingkungan. Menurut teori ini, proses belajar akan berjalan baik bila materi pelajaran yang baru beradaptasi dengan struktur kognitif yang telah dimiliki oleh anak (Thobroni \& Mustofa, 2011).

Kelebihan metode pretend play adalah memupuk daya cipta, karena simulasi dilakukan dengan kreasi siswa masing-masing memainkan perannya, merangsang siswa untuk menjadi terampil dalam menanggapi suatu hal dan bertindak secara spontan, tanpa memerlukan persiapan dalam waktu lama dan memperkaya pengetahuan, sikap, dan ketrampilan serta pengalaman tidak langsung yang diperlukan dalam menghadapi berbagai situasi sosial yang problematik (Rahyubi, 2012).

Berdasarkan latar belakang ini peneliti tertarik melakukan penelitian, yang tujuannya untuk mengetahui Terapi Bermain Pretend Play untuk Perkembangan Kognitif Anak Retardasi Mental di SDLB Kabupaten Lamongan.

\section{METODE PENELITIAN}

Penelitian ini menggunakan desain penelitian ini adalah Quasy Eksperimen (eksperimen semu) dengan pendekatan Pre-Post Tes Control Design.(Nursalam. 2013) Penelitian dilakukan pada bulan September 2017 sampai Maret 2018, lokasi penelitian dilakukan di SDLB Kabupaten Lamongan. Populasi dalam penelitian ini adalah Anak retardasi mental di seluruh SLB Kabupaten Lamongan, yang sejumlah 96 anak. Sampel pada penelitian ini adalah Anak Retardasi mental kelas IV di SDLB Kabupaten Lamongan yang memenuhi kriteria inklusi yaitu sebanyak 30 anak. Dalam penelitian ini menggunakan tehnik teknik purposive sampling. Variabel independen dalam penelitian ini adalah Terapi bermain Pretend Play. Variabel dependen dalam penelitian ini adalah Perkembangan kognitif anak retardasi mental. Penelitian ini bertujuan untuk mencari Pengaruh Terapi Bermain Pretend Play Terhadap Perkembangan Kognitif Anak Retardasi Mental di SDLB Lamongan dengan menggunakan uji Wilcoxon Sigmed Rank. 


\section{HASIL DAN PEMBAHASAN}

Tabel 1 Karakteristik Jenis Kelamin Responden Anak Retardasi Mental di SDLB Kabupaten Lamongan, 2018.

\begin{tabular}{lcc}
\hline \multicolumn{1}{c}{ Jenis Kelamin } & Jumlah & Prosentase (\%) \\
\hline Laki-laki & 19 & $63,3 \%$ \\
Perempuan & 11 & $36,7 \%$ \\
\hline \multicolumn{1}{c}{ Jumlah } & 30 & $100 \%$ \\
\hline
\end{tabular}

Berdasarkan tabel 1 menunjukkan bahwa sebagian besar anak retardasi mental berjenis kelamin laki-laki sebanyak 19 anak (63,3\%) dan hampir setengah anak retardasi mental berjenis kelamin perempuan sebanyak 11 anak $(36,7 \%)$.

Tabel 2 Karakteristik Umur Responden Anak Retardasi Mental di SDLB Kabupaten Lamongan, 2018

\begin{tabular}{lcc}
\hline \multicolumn{1}{c}{ Umur } & Jumlah & Prosentase \\
\hline 6-10 tahun & 5 & $16,7 \%$ \\
$11-15$ tahun & 22 & $73,3 \%$ \\
$>16$ tahun & 3 & $10,0 \%$ \\
\hline \multicolumn{1}{c}{ Jumlah } & 30 & $100 \%$ \\
\hline
\end{tabular}

Berdasarkan tabel 2 menunjukkan bahwa sebagian besar anak retardasi mental berumur 11-15 tahun sebanyak 22 anak (73,3\%), dan sebagian kecil anak retardasi mental berumur $>16$ tahun sebanyak 3 anak $(10,0 \%)$.

Tabel 3 Distribusi Frekuensi Kemampuan Kognitif Responden Sebelum Dilakukan Terapi Bermain Pretend play di SDLB Kabupaten Lamongan, 2018

\begin{tabular}{lcccc}
\hline \multirow{2}{*}{$\begin{array}{c}\text { Kemampuan } \\
\text { Kognitif }\end{array}$} & \multicolumn{4}{c}{ Sebelum Terapi Bermain Pretend play } \\
\cline { 2 - 5 } \multicolumn{1}{c}{ Klp. A } & $\boldsymbol{\%}$ & $\begin{array}{c}\text { Klp. } \\
\text { B }\end{array}$ & $\%$ \\
\hline Baik & 1 & 6,7 & 0 & 0 \\
Cukup & 4 & 26,7 & 3 & 20 \\
Kurang & 10 & 66,7 & 12 & 80 \\
\hline \multicolumn{1}{c}{ Jumlah } & 15 & 100 & 15 & 100 \\
\hline
\end{tabular}

Berdasarkan tebel 4.3 diatas diketahui bahwa sebelum dilakukan terapi terdapat 30 anak kelas IV di Kabupaten Lamongan yang di bagi 15 anak kelompok A dan 15 anak kelompok B, pada kelompok A kemampuan kognitif anak setengahnya memiliki kognitif kurang yaitu $10(66,7 \%)$ anak dan sebagian pada kelompok B yaitu 12 (80\%) anak, sedangkan anak yang memiliki kemampuan kognitif baik pada kelompok A yaitu 1 (10\%) anak dan sedangkan sebagian pada kelompok B tidak ada satupun yaitu $0(0 \%)$ anak yang memiliki kognitif baik. 
Tabel 4 Distribusi Frekuensi Kemampuan Kognitif Responden Sesudah Dilakukan Terapi Bermain Pretend play di SDLB Kabupaten Lamongan, 2018.

\begin{tabular}{lcccc}
\hline \multicolumn{1}{c}{$\begin{array}{c}\text { Kemampuan } \\
\text { Kognitif }\end{array}$} & $\begin{array}{r}\text { Klp. } \\
\text { A }\end{array}$ & \% & Klp. B & \% \\
\hline Baik & 5 & 33,3 & 13 & 86,7 \\
Cukup & 4 & 26,7 & 2 & 13,3 \\
Kurang & 6 & 40,0 & 0 & 0 \\
\hline \multicolumn{1}{c}{ Jumlah } & 15 & 100 & 15 & 100 \\
\hline
\end{tabular}

Berdasarkan tabel 4.4 diatas diketahui bahwa setelah dilakukan terapi pada kelompok A yang tidak diberi terapi sebagian besar anak memiliki kemampuan kognitif kurang yaitu $6(40,0 \%)$ anak dan pada kelompok B yang diberi terapi tidak ada satupun yaitu $0(0 \%)$ anak yang memiliki kognitif kurang, sedangkan sebagian anak yang memiliki kemampuan kognitif baik pada kelompok A yaitu 5 (33,3\%) anak dan sedangkan sebagian anak yang memiliki kemampuan kognitif baik pada kelompok B yaitu 13 (86,7\%) anak.

Berdasarkan hasil perhitungan menggunakan uji Wilcoxon Signed Rank Test yang dianalisa menggunakan program SPSS for windows antara terapi bermain pretend play dengan perkembangan kognitif, dengan hasil dari uji Wilcoxon ( $\mathrm{p}$ value 0,000) sehingga didapatkan signifikan 0,000 < 0,05 dengan demikian H1 diterima yang artinya ada Pengaruh Terapi Bermain Pretend Play Terhadap Perkembangan Kognitif Anak Retardasi Mental di SDLB Kabupaten Lamongan Tahun 2018

Berdasarkan tebel 3 diatas diketahui bahwa sebelum dilakukan terapi terdapat 30 responden kelas IV di Kabupaten Lamongan yang di bagi 15 responden kelompok A dan 15 responden kelompok B, pada kelompok A kemampuan kognitif responden setengahnya memiliki kognitif kurang yaitu $10(66,7 \%)$ responden dan sebagian pada kelompok B yaitu $12(80 \%)$ responden.

Dalam penilaian kognitif sebelum dilkukan terapi bermain pretend play pada anak retardasi mental di SDLB Kabupaten Lamongan terdapat satu anak yang memiliki kemampuan kognitif dengan kriteria baik dalam kelompok A dan sedangkan pada kelompok B tidak ada anak yang memiliki kemampuan kognitif dengan kriteria baik, sebagian besar anak memilikai kemampuan kognitif dengan kriteria kurang yaitu 22 (73,3\%) dari 30 anak hal ini memang menunjukkan bahwa kemampuan kognitif anak dengan retardasi mental sangat rendah dibandingkan dengan anak normal.

Kognitif adalah perolehan, penataan dan penggunaan pengetahuan yang meliputi setiap perilaku mental yang berhubungan dengan pemahaman, pertimbangan, pengolahan informasi, pemecahan masalah, kesenjangan, dan keyakinan (Dahar, Ratna Wilis , 20011), sedangakan retardasi mental atau tunagrahita adalah istilah yang digunakan untuk menyebut anak yang mempunyai 
kemampuan intelektual dibawah rat-rata. Dalam kepustakaan bahasa asing digunakan istililah-istilah mental retardation, mentally retarded, mental deficiency, mental defective, dan lain-lain (Somantri, 2012).

Anak retardasi mental berkembang dengan laju yang berbeda, pada tahap pertumbuhan mereka karena terdapat ketidaknormalan pada otak mereka selain itu anak retardasi mental juga mengalami fase vegetatif total yang membatasi perilaku dan pergerakan anak. (Sudarna 2014)

Berdasarkan tabel 4 diatas diketahui bahwa setelah dilakukan terapi pada kelompok B memiliki kemapuan kognitif baik yaitu 13 (86,7\%) anak, sedangkan pada kelompok A yang tidak diberi terapi memiliki kemampuan kognitif baik yaitu $5(33,3 \%)$ anak.

Bergen dalam Suminar, Dewi retno (2009) menunjukkan bahwa pretend play memiliki pengaruh terhadap perkembangan kognitif anak. Dalam penelitian tersebut digambarkan bahwa perkembangan kognitif anak adalah menyangkut kemampuan dalam perencanaan, negosiasi, problem solving dan pencapaian tujuan. Dalam perkembangannya bahwa peran pretend play dalam perkembangan kognitif adalah mempengaruhi kesiapan anak dalam mempelajari matematika, kemampuan dalam bahasa, representational competence, Kemampuan dalam fungsi kognitif dan kontrol impuls-impuls, serta kemampuan dalam memecahkan masalah atau problem solving skill.

Dalam penelitian ini fungsi dari terapi bermain pretend play sangat jelas dimana terdapat perbedaan yang sangat signifikan terutama pada kelompok perlakuan dimana terdapat peningkatan kemampuan kognitif anak degan retardasi mental yang dapat dilihat pada tabel 4.4 diperlihatkan bahwa ada 13 responden yang mengalami peningkatan kognitif anatara sebelum dan sesudah terapi bermain pretend play dan tidak ada yang mengalami penurunan kemampuan kognitif antara sebelum dan sesudah terapi bermain pretend play. Hal ini dimungkinan karena dimana informasi yang diterima otak akan lebih mudah diterima jika dalam bentuk permainan. Didalam terapi bermain pretend play salah satu pelatihannya adalah melalui alat permainan, selaian untuk melatih daya ingat juga untuk mengenal benda-benda sekitar. Ini dikarenakan anak lebih mudah untuk mengingat dan belajar bila diperlihatkan gambar atau alat benda permainan, kejadian, tingkah laku maupun konsep-konsep abstrak. ( Handayani Muryantinah. 2014). Dengan melihat gambar atau alat benda permainan, anak retardasi mental akan membentuk gambaran mental atau mental image yang jelas dan relatif permanen dalam benaknya. Bila materi tersebut hanya diucapkan saja mereka akan mudah melupakannya karena kognitif mereka dibawah rata-rata orang normal.(Maryatun purwaningsih, Wahyu 2011).

Berdaskan tabel 5 diketahui hasil dari uji Wilcoxon (p value 0,000 ) sehingga didapatkan signifikan 0,000 $<0,05$ dengan demikian $\mathrm{H} 1$ diterima yang artinya ada Pengaruh Terapi Bermain Pretend play Terhadap Perkembangan Kognitif Anak Retardasi Mental di SDLB Kabupaten Lamongan Tahun 2018. 
Pretend play adalah bentuk permainan yang didalamnya mengandung unsur berpura-pura. Permainan ini berbeda dengan role play, karena dalam pretend play selain terdapat sejumlah aturan, digunakan sejumlah peralatan tertentu yang menunjang permainan (Somantri, Sutjihati, 2011). Kognitif adalah perolehan, penataan dan penggunaan pengetahuan yang meliputi setiap perilaku mental yang berhubungan dengan pemahamn, pertimbangan, pengolahan informasi, pemecahan masalah, kesenjangan, dan keyakinan (Soetjiningsih, 2015).

Dalam penelitian ini jelas memperlihatkaan bahwa terdapat pengaruh terapi bermain pretend play terhadap kemampuaan kognitif anak retardasi mental dimana dari 15 anak yang mendapat terapi bermain pretend play menunjukkan 13 anak yang memiliki keberhasilan peningkaatan kemampuan kognitif, namun harus diperhatikan bahwa keberhasilan terapi bermain pretend play banyak dipengaruhi oleh beberapa faktor yang lain: berat ringannya gejala, umur anak semakin dini anak mendapat terapi, informasi yang ditangkap oleh anak, kemampuan berbicara dan berbahasa, intensitas terapi, keberhasilan terapi anak retardasj mental juga tergantung pada dukungan seluruh keluarga sejak anak bangun pagi hingga tidur di malam hari.

\section{KESIMPULAN}

Berdasarkan hasil penelitian menyimpulkan beberapa hal sebagai berikut :

1) Sebagian besar responden memiliki kemampuan kognitif kurang sebelum dilakukan terapi bermain pretend play di SDLB kabupaten Lamongan Tahun 2018.

2) Hampir seluruh responden memiliki kemampuan kognitif baik setelah dilakukan terapi bermain pretend play di SDLB kabupaten Lamongan Tahun 2018.

3) Dari uji Wilcoxon ( $\mathrm{p}$ value 0,000) sehingga didapatkan signifikan 0,000 $<0,05$ dengan demikian H1 diterima yang artinya ada Pengaruh Terapi Bermain Pretend play Terhadap Perkembangan Kognitif Anak Retardasi Mental di SDLB Kabupaten Lamongan Tahun 2018.

Beberapa hal yang dapat direkomendasikan oleh peneliti terkait hasil penelitian adalah sebagai berikut :

\section{1) Bagi Tempat Penelitian}

Hasil penelitian ini diharapkan guru atau pengajar kebutuhan khusus dapat menerapakan terapi pretend play tersebut dalam metode pembelajaran agar membantu perkembangan kognitif anak dengan retardasi mental.

2) Bagi Profesi Keperawatan

Hasil dari penelitian ini diharapkan dapat memberikan informasi kepada tenaga kesehatan tentang perkembangan kognitif anak retardasi mental dengan terapi pretend play. 


\section{DAFTAR PUSTAKA}

Ariani, Soeselo, \& Surilena. 2014. Karakteristik Pola Asuh dan Psikopatologi Orang Tua Penyandang Retardasi Mental Ringan di Sekolah Luar Biasa-C (SLBC) Harapan Ibu. Damianus Journal of Medicine Vol.13 hal 74-83.

Ariyani, I N. 2013. Pengaruh Bermain Congklak Terhadap Peningkatan Kemampuan Berhitung Pada Anak Retardasi Mental. Hal 1.

Dahar, Ratna Wilis. 2011. Teori-Teori Belajar dan Pembelajaran. Jakarta: Erlangga.

Desmita. 2015. Psikologi Perkembangan. Bandung: PT. Remaja Rosdakarya Offset.

Handayani Muryantinah Mulyo. 2014. Paradigma Konstruktivis PIAGET. psyche.psikologi.unair.ac.id diakses pada tanggal 23 November 2017

Kemenkes RI. 2014. Situasi Penyandang Disabilitas. Jakarta: Bakti Husada

Maryatun; Purwaningsih, Wahyu. 2011. Buku Ajar Keperawatan Anak 1. Yogyakarta:

Nursalam. 2013. Metodologi Penelitian Ilmu Keperawatan: Pendekatan Praktis. Edisi 3. Jakarta. Salemba Medika.

Prihtiyaningsih, Nurvi. 2017. Efektivitas Metode Pretend Play Terhadap Kemampuan Interaksi Sosial Anak Autistik Kelas II SDLB di SLB Ma'arif Muntilan. Jurnal Widia Ortodidaktika Vol 6 No 1

Rahyubi, Heri. 2012. Teori-Teori Belajar dan Aplikasi Pembelajaran Motorik. Bandung: Nusamedia.

Soetjiningsih. 2015. Tumbuh Kembang Anak. Jakarta: EGC

Somantri, Sutjihati. 2012. Psikologi Anak Luar Biasa. Bandung: Refika Aditama.

Subini, Nini. 2012. Panduan Mendidiki Anak Dengan Kecerdasan di Bawah RataRata. Jakarta: Javalitera.

Sudarna. 2014. PAUD (Pendidikan Anak Usia Dini) Berkarakter Melejitkan Kepribadian Anak Secara Utuh. Yogyakarta: Distribusi Nasional. 
Suminar, Dewi Retno. 2009. Membangun Karakter Anak Melalui Pretend Play Vol VI, No. 1. Jurnal Psikologi Indonesia hal 1-11

Thobroni, Muhammad; mustofa, Arif. 2011. Belajar dan Pembelajaran: Pengembangan Wacana dan Praktik Pembelajaran dalam Pembangunan Nasional. Yogyakarta: Ar-Ruzz Media. 